\section{Traditional circumcision - the unkindest cut of all}

'What kind of ritual is this that it now is killing our children?'

(mother of a male Xhosa initiate) ${ }^{1}$

To the Editor: Twenty years ago two Eastern Cape urological surgeons documented their experience with treating initiates of umkhwetha, the ancient custom of ritual circumcision practised by the amaXhosa people of southern Africa. Crowley and Kesner followed up 45 consecutive patients and documented a mortality rate of $9 \% .{ }^{2}$ Recent press reports from the Eastern Cape claim an annual death rate of more than 70 per year. ${ }^{3}$ The death toll for the 2010 winter initiation period stood at 40 at the time of writing. ${ }^{4}$ These statistics not only point to the fact that little has changed, but suggest that the situation may in fact be deteriorating.

While the deaths write headlines, the misery goes much further; 150 youths are said to be attending hospitals in Eastern Cape for 'botched circumcisions, ${ }^{4}$ with results ranging from wound infections to gangrene to total penile loss. Twenty-two young men are reported to have suffered 'penile amputations.'

Much academic socio-medical research has been done to understand and explain the complex circumstances leading to these deaths and mutilations. ${ }^{1,5}$ In addition to this important research, countless programmes have attempted to sanitise the practice. Yet if progress is counted in lives, the efforts appear to have been wasted.

Kepe has eloquently mapped the terrain of the current crisis into two distinct components. ${ }^{5}$ Firstly a 'public health nightmare' exists, created by the morbidity and mortality caused by ritual circumcision among the amaXhosa. Secondly, there is mounting tension between traditional leaders and government. Traditional leaders cite interference and violation of cultural rights, while the government has instituted prevention programmes and in 2001 promulgated the Circumcision Act in the Eastern Cape.

Dan Ncayiyana, editor of the $S A M J$, has campaigned for changes to circumcision practice. He has labelled the circumcision schools as 'deadly' and their claims of offering a genuine rite of passage as fake. ${ }^{6} \mathrm{He}$ sees solutions in certified training of traditional surgeons, a registry of accredited schools, and regular inspection of the schools.

Considering what little progress the many initiatives by government and health care providers have made, is it not time to recognise that the root of the problem lies with traditional leaders? Until government finds the courage to prosecute in court traditional leaders in whose name the circumcision schools are run, no progress can be achieved in the fight against this preventable loss of life.

\section{John Lazarus}

Division of Urology

Groote Schuur Hospital and

University of Cape Town

j.lazarus@uct.ac.za

1. Peltzer K, Nqeketo A, Petros G, Kanta X. Traditional circumcision during manhood initiation rituals in the Eastern Cape, South Africa: a pre-post intervention. BMC Public Health 2008; 8: 64.

2. Crowley IP, Kesner KM. Ritual circumcision (Umkhwetha) amongst the Xhosa of the Ciskei. Br J Urol 1990; 66(3): 318-321.

3. Times Live. http://www.timeslive.co.za/local/article522833.ece/DA-Circumcisions-must-be-done-in-hospitals (accessed 28 June 2010).

4. City ensures circumcision schools are safe. Cape Times 1 July 2010, p. 4.

5. Kepe T. 'Secrets' that kill: Crisis, custodianship and responsibility in ritual male circumcision in the Eastern Cape Province, South Africa. Social Science \& Medicine 2010; 70: 729-735.

6. Ncayiyana DJ. Astonishing indifference to deaths due to botched ritual circumcision (From the Editor). S Afr Med J 2003; 93: 546.

\section{Clinical haematology training in South Africa}

To the Editor: I read Dr Mlombe's letter on clinical haematology training in South Africa in the June $S A M J^{1}$ with interest. Patients with haematological disorders must be treated with a seamless connection between the laboratory and the clinic. The FCPath (SA) (Haem) (Fellowship of the Colleges of Pathologists of South Africa in Haematology) final exam also includes clinical cases. ${ }^{2}$

I was the secretary of the South African Society for Haematology (SASH) at the time of the inception of the subspecialty of clinical haematology in 1997, ${ }^{3}$ and would like to sketch the background. Before that time haematologists could either train as haematological pathologists, or as paediatricians or physicians. In the latter two specialties there were no formal qualifications in haematology. During the early 1990s eminent South African haematologists tried to unify the profession of haematology, so that haematologists would be equally comfortable in the laboratory and at the bedside, as recommended by the International Society of Haematology, ${ }^{4,5}$ A similar model is followed in the UK, where haematologists first complete an MRCP (Membership of the Royal College of Physicians), followed by the FRCPath (Fellowship of the Royal College of Pathologists in Haematology) by examination, before being eligible for registration as a specialist. The training is regulated by the Joint Royal Colleges of Physicians' Training Board (JRCPTB). ${ }^{6}$

However, in the mid-1990s the then Interim National Medical and Dental Council supported the idea of subspecialties rather than creating new specialties. Thus the subspecialty of clinical haematology came into being, which allows haematological pathologists to gain clinical training, and physicians and paediatricians to gain laboratory training. This is similar to training in the subspecialty of infectious diseases, where there is cross-training in microbiology laboratory and clinical medicine. ${ }^{7}$ This does not affect the significance of dedicated pathologists. Specialists from various backgrounds train in the subspecialties of intensive care and gastro-enterology.

As mentioned in the letter, clinical haematology is regarded purely as a subspecialty of internal medicine in many parts of the world. The curriculum does not involve significant laboratory training, and this model works well in many countries. In my opinion, however, clinical haematologists must be trained in both laboratory and clinical medicine, which equips clinical haematologists trained in South Africa to be the best professionals to manage haematological conditions. The subspecialty is growing. It is fortuitous that 2010 is the centenary of the publication of the seminal Flexner Report, ${ }^{8}$ which emphasises the importance of basic medical science in medical education.

\section{J Coetzee}

Department of Haematology and Cell Biology

University of the Free State

Bloemfontein

coetzeemj@ufs.ac.za

1. Mlombe YB. Clinical haematology training in South Africa for fellows with a primary specialty of internal medicine - what's in a name? S Afr Med J 2010; 100(6): 334-336.

2. The Colleges of Medicine of South Africa. Regulations for admission to the Fellowship of the College of Pathologists of South Africa in Haematology, FCPath (SA) Haem. http://www.collegemedsa.ac.za/force_ download.asp?Path=Documents $\backslash$ doc $\_80 . p d f \& N a m e=F C \% 20$ Path(SA)\%20 Haem\%20Regulations (accessed 25 July 2010).

3. The Interim National Medical and Dental Council of South Africa: Regulations relating to the registration of the subspecialities of medical practitioners and dentists: amendment. Government Gazette 17 January 1997; Regulation 67[17721], Paragraph 4 (a) (xvi). 